\title{
NUMERICAL TESTS OF THE VIRTUAL HUMAN MODEL RESPONSE UNDER DYNAMIC LOAD CONDITIONS DEFINED IN FEDERAL AVIATION REGULATION PART 23.562 AND 25.562 - PRELIMINARY STUDY
}

\begin{abstract}
The main aim of the presented research was to check mechanical response of human body model under loads that can occur during airplane accidents and compare results of analysis with some results of experimental tests described in literature. In simulations, new multi-purpose human body model, the VIRTHUMAN, was used. The whole model, as well as its particular segments, was earlier validated based on experimental data, which proved its accuracy to simulate human body dynamic response under condition typical for car crashes, but it was not validated for loads with predominant vertical component (loads acting along spinal column), typical for airplane crashes. Due to limitation of available experimental data, the authors focused on conducting calculations for the case introduced in 14 CFR: Parts 23.562 and 25.562, paragraph (b)(1), knowing as the $60^{\circ}$ pitch test. The analysis consists in comparison of compression load measured in lumbar section of spine of the FAA HIII Dummy (experimental model) and in the Virthuman (numerical model). The performed analyses show numerical stability of the model and satisfactory agreement between experimental data and simulated Virthuman responses. In that sense, the Virthuman model, although originally developed for automotive analyses, shows also great potential to become valuable tool for applications in aviation crashworthiness and safety analyses, as well.
\end{abstract}

\section{Introduction}

In October 2009, the new rule for dynamic testing of seats included in 14 Code of Federal Regulations (CFR) Part 25.562 was finally implemented by Federal Aviation Administration (FAA). The new requirements add stringent dynamic tests

\footnotetext{
${ }^{1}$ Warsaw University of Technology, Institute of Aeronautics and Applied Mechanics, ul. Nowowiejska 24,00-665 Warsaw, Poland; Email: luclin@meil.pw.edu.pl, tomekn@meil.pw.edu.pl

${ }^{2}$ University of West Bohemia, New Technologies Research Centre Univerzitni 8, 30614 Plzen, Czech Republic; Email: jvychyti@ntc.zcu.cz,hyncik@ntc.zcu.cz.
} 
for seat certification. The main aim of including these crashworthiness requirements is significant improving the level of pilot's and passenger's safety in case of a crash [1]. On 1 May 2011, an agreement between the European Union and the United States on concern cooperation in the regulation of civil aviation safety was entered into force. The purpose of the agreement is to enable the reciprocal acceptance of findings of compliance and approvals, and ensure regulatory cooperation and harmonisation between the United States and the EU as regards airworthiness approvals and monitoring of civil aeronautical products [2].

The process of the new regulations implementation lead to the necessity of conducting multiple experimental investigation to establish testing procedures and defining appropriate research and design tools [3-8].

On the other hand, intensive development of computers and computational methods enables significant growth of research activity in the field of numerical simulations. Such theoretical approach became very popular due to its main advantages - less costs, research stand arrangements and relatively easy way to simulate various crash scenarios.

Common software packages used for crash simulation (in automotive as well as in aviation industry) offer variety of models of the human body, including dummies e.g. [9, 10], [see also other packages handbooks]. The models, depending on their destination, differ from each other in the level of complexity and the range of potential application (e.g. limited only to frontal impact or only to side impact). This second feature is especially important in the case of numerical modelling of the dummies used in experimental tests. An important research problem is serious limitation of the dummies model's biofidelity, which very often causes that the model dynamic response, especially in more complex crash conditions, is not human-like.

Due to the limitations mentioned above, one can observe increasing tendency for development of numerical models in last years. These models allow one to simulate body dynamic response and assess the level of safety in more realistic way, even under complex dynamic load conditions (e.g. rollover car crashes, aviation accidents), that occur in various modes of transportations. However, design and implementation of numerical models of a human body requires conducting a validation process. It's the fundamental factor that decides about the possibility of their further application.

Recently, several computer models have been developed to represent seats/restraint systems as well as human body in a crash. The use of these models during the design phase of seat restraint systems and airplane interior is encouraged [4]. FAA allows for using computer modelling analytical techniques validated by dynamic tests to provide all pass/fail criteria identified in FAR 23.562 and 25.562 and for demonstrating compliance to these regulations. Specially developed guidance [7] determine necessary conditions for application of computer modeling in support of dynamic testing or in lieu of dynamic testing during certification process. This document specifies also the combination of computer codes and occupant models 
using in support of design and certification of seats. It is emphasized there that the list is no exhaustive and that other codes and occupant models, shown to be equivalent, may be utilized as well. It means that the way to development of the new more advanced and accurate numerical analyses tools (as e.g. human body models) are widely open. One of such multi-purpose virtual human body models, which potentially could become a very powerful research tool, is a special model called the VIRTHUMAN [11-13]. The whole model, as well as its particular segments, has been validated based on the available experimental data [13], which proved its accuracy to simulate human body dynamic response under condition typical for car crashes, but it is not validated for loads with predominant vertical component (loads acting along spinal column), typical for airplane crashes.

This paper concern preliminary numerical investigation of the VIRTHUMAN human body model behaviour under dynamic load conditions defined in the FAR (Federal Aviation Regulations) Part 23.562 and 25.562. The main aim of the presented research is to check mechanical response of virtual human body model under loads that can occur during airplane accidents, and to compare results of analysis with some results of experimental test described in literature [14]. Due to limitation of available experimental data, the authors focused on conducting calculations for the case introduced in paragraph (b)(1), knowing as the $60^{\circ}$ pitch test. The analysis consists in comparison of compression load measured in lumbar section of spine of FAA HIII Dummy (experimental model) and in Virthuman (numerical model). The performed calculations are expected to be the first, initial phase of the research devoted to Virthuman model validation in relation to its further usefulness as a research tool in the field of aviation crashworthiness and safety.

\section{Dynamic testing method}

\subsection{Seat certification requirements}

The regulations 14 CFR Part 23.562 and 25.562 forced by the FAA specify some necessary conditions, from occupant's safety point of view, for successful certified the seats. Each seat and restraint system for the use in airplane must be designed to protect each occupant during an emergency landing when occupant, represented by an anthropomorphic test dummy (ATD), is exposed to the loads resulting from conditions prescribed in 23.562 (b)(1), (b)(2) for normal, utility, acrobatic and commuter airplanes and 25.562 (b)(1), (b)(2) for transport airplanes - respectively. Those paragraphs define two dynamic tests scenarios requirements: Test $1-(b)(1)$ and Test $2-(b)(2)$, while paragraphs 23.562 (c) and 25.562 (c) formulate some injury criteria, used to assess, if loads and accelerations acting on chosen body segments are below the level assumed to be dangerous for the human being. The dummy dynamic response must be correlated with those injury criteria. 
The formulated procedures require using the ATD defined by 49 CFR Part 572, subpart B or an FAA - approved equivalent $[7,15]$.

\subsubsection{Emergency landing dynamic conditions - Test 1}

This test simulates the aircraft crash into the ground with the airplane's longitudinal axis canted downward by $30^{\circ}$ with respect to the horizontal plane. When the tests are conducted on horizontal sleds, the seat/restraint system must be oriented in such a way that the horizontal plane of the airplane is pitched up by $60^{\circ}$ (Fig. 1). According to the fact that in this case vertical component of impact force is predominant, the main aim of the test 1 is the assessment of the load acting on lumbar spine of the occupant.

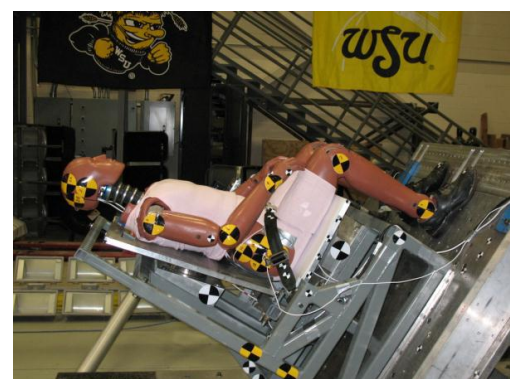

Fig. 1. Test 1. Horizontal - vertical impact. Experimental stand arrangement [3]

Dynamic test requirements for Part 23.562 as well as for 25.562 are generally similar, and define such conditions like: minimum change in velocity, maximum time to deceleration peak occurring and the value of this peak. The main difference concerns the values of those quantities. Part 23 requires for the seat to be installed in the first row of the airplane conducting test with deceleration peak of $19 \mathrm{~g}$ and time to peak $0.05 \mathrm{sec}$., while for all other with $15 \mathrm{~g}$ and time to peak 0.06 . Table 1 summarizes the dynamic test 1 requirements for 14 CFR parts 23 and 25, section 562.

Table 1.

Dynamic test 1 requirements for 14 CFR: Parts 23.562 and 25.562

\begin{tabular}{|l|c|c|}
\hline $\begin{array}{l}\text { DYNAMIC TEST 1 } \\
\text { REQUIREMENTS }\end{array}$ & $\begin{array}{c}\text { PART 23.562 } \\
\text { Normal, utility, acrobatic } \\
\text { and commuter airplanes }\end{array}$ & $\begin{array}{c}\text { PART 25.562 } \\
\text { Transport airplanes }\end{array}$ \\
\hline Test Velocity - Ft/Sec & $31(9.45 \mathrm{~m} / \mathrm{s})$ & 35 \\
Seat Pitch Angle - Deg. & 60 & 60 \\
Seat Yaw Angle - Deg. & 0 & 0 \\
Peak Acceleration - G's & $19 / 15$ & 14 \\
Time to Peak - Sec & $0.05 / 0.06$ & 0.08 \\
Floor Deformation - Deg. & None & None \\
\hline
\end{tabular}


2.1.2. Emergency landing dynamic conditions - Test 2

This test simulates situation, when the aircraft hit the ground barrier (secondary impact) after first contact with the ground. In this case, the most important force and acceleration affecting an occupant acts in horizontal plane (Fig. 2). The main aim of test 2 is to determine dynamic body response and examine the protection provided by the whole harness system. In order to realize this aim, the seat must be rotated in horizontal plane (yawed by 10 degrees), that results in the greatest load on the shoulder harness.
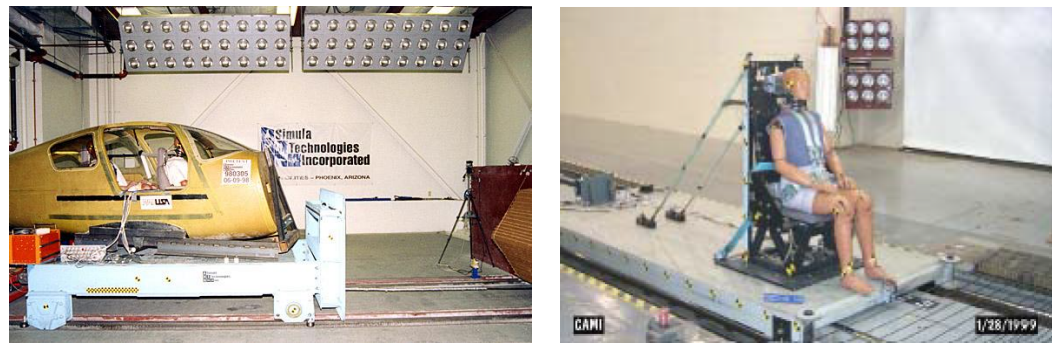

Fig. 2. Test 2. Horizontal impact. Experimental stand arrangement [3, 14]

Dynamic test requirements for both Parts: 23.562 and 25.562 define the conditions like: minimum change in velocity, maximum time to deceleration peak and the value of this peak. The main difference concerns the values of those quantities. Both parts of the regulations take into account floor deformation resulting from the contact with the ground by special arrangement. The floor rails or attachment devices used to attach the seat/restraint system to the airframe structure must be preloaded to misalign them with respect to each other by at least 10 degrees vertically [14] and one of the rails or attachment devices must be preloaded to misalign it by 10 degrees in roll [14]. Part 23 requires for the seat to be installed in the first row of the airplane conducting the test with a deceleration peak of $26 \mathrm{~g}$ and time to peak of $0.05 \mathrm{sec}$., while for the other part deceleration peak equals $21 \mathrm{~g}$ and time to peak $0.06 \mathrm{sec}$. Table 2 summarizes the dynamic test 2 requirements for $14 \mathrm{CFR}$ parts 23 and 25, section 562 .

Table 2.

Dynamic test 2 requirements for 14 CFR: Parts 23.562 and 25.562

\begin{tabular}{|l|c|c|}
\hline DYNAMIC TEST 2 & PART 23.562 & PART 25.562 \\
REQUIREMENTS & Utility airplane & Transport airplane \\
\hline Test Velocity - Ft/Sec & $42(12.8 \mathrm{~m} / \mathrm{s})$ & $44(13.4 \mathrm{~m} / \mathrm{s})$ \\
Seat Pitch Angle - Deg. & 0 & 0 \\
Seat Yaw Angle - Deg. & 10 & 10 \\
Peak Acceleration - G's & $26 / 21$ & 16 \\
Time to Peak - Sec & $0.05 / 0.06$ & 0.09 \\
Floor Deformation - Deg. & 10 Pitch/10Roll & 10 Pitch/10Roll \\
\hline
\end{tabular}




\subsubsection{Injury criteria and tolerance levels}

As was mentioned earlier, dynamic response, characterized by time histories of forces and accelerations measured in different segments of the ATD's body, must satisfy particular injury criteria [16, 17]. The criteria can be briefly described as follows, while Table 3 shows tolerance level of those quantities determined in regulations:

Tolerance level determined in Parts: 23.562(c) and 25.562(c) ${ }^{1}$

Table 3.

\begin{tabular}{|l|c|c|}
\hline $\begin{array}{l}\text { Tolerance level determined } \\
\text { in FAA regulations }\end{array}$ & $\begin{array}{c}\text { PART 23.562 } \\
\text { Utility airplane }\end{array}$ & $\begin{array}{c}\text { PART 25.562 } \\
\text { Transport airplane }\end{array}$ \\
\hline Spinal Compressive Load (lbf) & $1500(6672 \mathrm{~N})$ & $1500(6672 \mathrm{~N})$ \\
\hline HIC (unitless) & 1000 & 1000 \\
\hline Femur Compressive Load $(\mathrm{lbf})$ & Not required & $2250(10013 \mathrm{~N})$ \\
\hline $\begin{array}{l}\text { Total belt strap loads }(\mathrm{lbf}) \\
\text { (one strap/two straps) }\end{array}$ & $\begin{array}{c}1750 / 2000 \\
(7784 / 8896 \mathrm{~N})\end{array}$ & $\begin{array}{c}1750 / 2000 \\
(7784 / 8896 \mathrm{~N})\end{array}$ \\
\hline
\end{tabular}

${ }^{1}$ Values given in regulations are originally expressed in imperial units. Loads expressed in SI units are given in parentheses.

\section{Spinal Compression Load Criterion}

This criterion specifies the maximum compression force measured between the lumbar spine and pelvis region of ATD's body.

\section{Head Injury Criterion (HIC)}

The results of the dynamic tests must show that the occupant is protected from serious head injury. For aviation purpose, it must be proved during dynamic test by calculating the HIC value. This criterion is based on relation between head's centre of gravity linear acceleration and time duration. It's defined as:

$$
H I C=\max \left\{\left(t_{2}-t_{1}\right)\left[\frac{1}{\left(t_{2}-t_{1}\right)} \int_{t_{1}}^{t_{2}} a(t) d t\right]^{2.5}\right\}
$$

where $t_{1}$ and $t_{2}$ is the initial and final integration time in seconds, respectively, and $a(t)$ is acceleration vs. time function in units of gravity $(\mathrm{g})$.

The HIC is calculated when contact with adjacent seats, structure, or other items in the cabin can occur.

\section{Femur Compressive Load Criterion}

This criterion specifies the maximum axially compressive loads acting on each dummy's femur. It's introduced to prevent leg injuries resulting from contact with seats or other structure. This criterion is used to certify the seats only in transport category (Part 25.562). 


\section{Safety Belts Load Criterion}

This criterion is based on measurement of the tension force in safety belts. It specifies the maximum tension loads in individual shoulder belt strap as well as a total loads in the case of using two shoulder straps. When shoulder segments of safety belt are no provided (for passengers of transport airplanes), tension limit is not required.

\subsection{Numerical test setup}

The simulation model was developed in the PAMCRASH software environment. PAMCRASH is a package used for crash simulation, analyzing occupant safety and optimizing component and vehicle design worldwide. Main field of its application is road safety and research work in automotive industry. However, it becomes more and more often used also in aerospace and aircraft engineering. Extensive database with numerical models of many materials creates a strong part of the software.

The model of the test stand arrangement (Fig. 4) is based on Crash Dynamics Laboratory sled test facility (Fig. 3) existing at National Institute for Aviation Research (NIAR) - research centre located in Wichita State University [8, 14, 18]. On this experimental stand one performed the sled tests described in [14], which were the reference for numerical analyses.

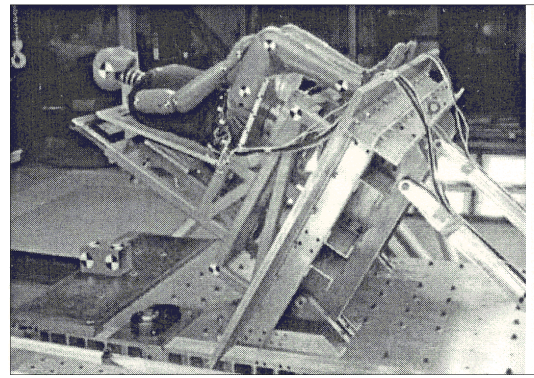

(a)

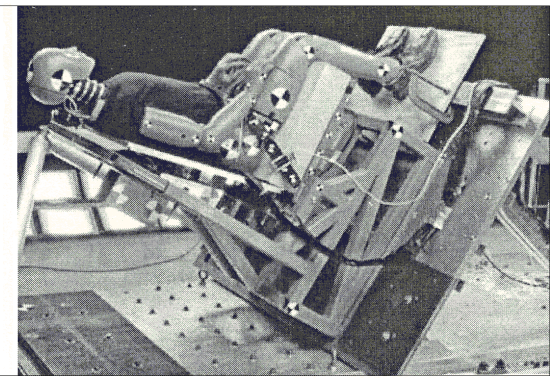

(b)

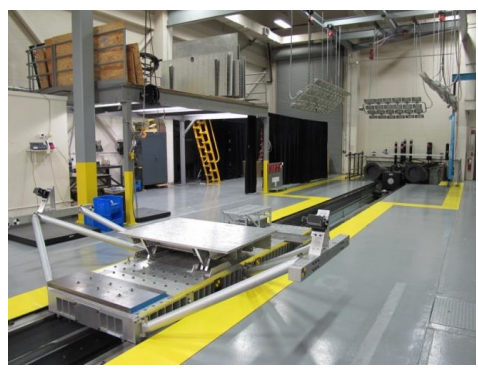

(c)

Fig. 3. Experimental stand: rigid seat (a) and cushioned seat (b) for $60^{\circ}$ tests, sled crash simulator (c) [8] 


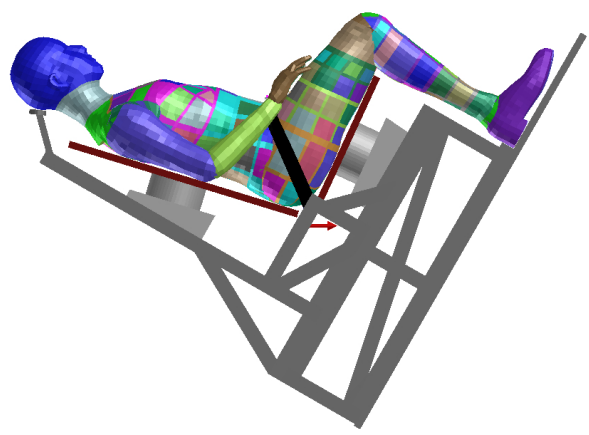

(a)

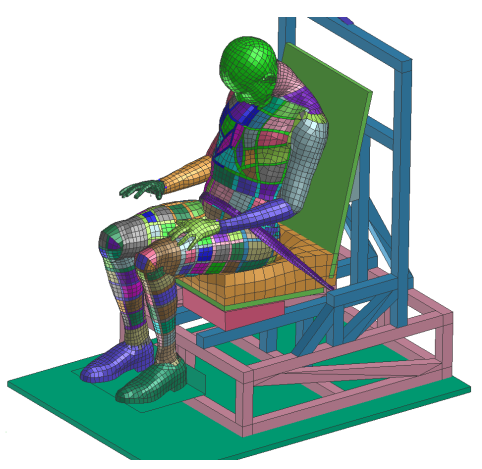

(b)

Fig. 4. Numerical model of the test facility: rigid seat (a) and cushioned seat (b)

The main elements of the numerical test setup (Fig. 4), like: floor plate, seat base steel frame, seat pan and seat back were modelled as rigid bodies using multibody method. Such approach allowed one to create simple and effective model of the test facility, which was good enough for preliminary testing due to the fact that any structural analysis of the seat structure wasn't performed.

The model of a safety belt system used in the presented analyses is a hybrid model composed of FE belt parts and segmented belts (spring-damper elements). The FE part is modelled as the portion of the webbing that contacts the occupant. It is represented by membrane elements. The segmented belts connect the end nodes of the FE belt to the frame with the pin joints. Such modelling makes it possible to include contact interactions between safety belts and the body in the analyses.

Most of the properties of contact interactions between the body and the seat, the feet and the platform, as well as between the body and the belts, such as: the type of contact and the values of some parameters (eg. friction and damping coefficients) were taken from the file containing the numerical sled test described in [13], which was validated in an experiment (or are very close to them). Material properties of the rigid sled (steel), the belts webing (nylon or polyester) and their characteristics were also taken from the same file. It should not influence the final results significantly due to the fact that the test setup arrangement was very similar. For modelling interaction between body and the seat elements, the BODY TO MULTIPLANE contact type was used with friction coefficient $\mu=0.15$ (Coulomb model). Contact interaction between the body and the FEM parts of safety belts were modelled using the EDGE TO EDGE contact type with friction coefficient $\mu=0.2$.

For the purpose of cushioned seat analysis, a special FEM model of a cushion was created. The model consists of 330 solid elements. The cushion was modelled using the GEN_NONLIN_STRAIN_RATE_FOAM material model [19] with compression characteristic (Fig. 5) prepared on the basis of the data given in $[5]$. 


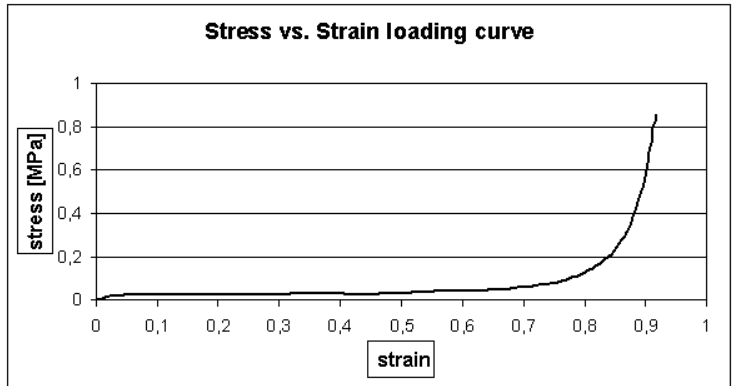

Fig. 5. Cushion compression loading characteristic

Cushion model parameters $[5,14]^{1}$

Table 4.

\begin{tabular}{|c|c|c|c|c|c|}
\hline Type & $\begin{array}{c}\text { Length } \\
{[\mathrm{m}]}\end{array}$ & $\begin{array}{c}\text { Width } \\
{[\mathrm{m}]}\end{array}$ & $\begin{array}{c}\text { Thickness } \\
{[\mathrm{m}]}\end{array}$ & Material properties [5] & $\begin{array}{c}\text { Density }) \\
{\left[\mathrm{km} / \mathrm{m}^{3}\right]}\end{array}$ \\
\hline Non - flot. & $\begin{array}{c}0.47 \\
(18.5 \mathrm{in} .)\end{array}$ & $\begin{array}{c}0.483 \\
(19 \text { in. })\end{array}$ & $\begin{array}{c}0.114 \\
(4.5 \text { in. })\end{array}$ & $\begin{array}{c}\text { Nawa3C450 with circ. coupons } \\
\text { of } 7.5 \text { in. diameter }\end{array}$ & $\begin{array}{c}68,9 \\
\left(4.3 \mathrm{lb} / \mathrm{ft}^{3}\right)\end{array}$ \\
\hline
\end{tabular}

${ }^{1}$ Original research values are expressed in imperial units. Here are given in parentheses.

In all cases, the crash was simulated by implementation of combination of initial and boundary conditions, which is a common procedure in numerical study. The test seat structure was initially rotated (see Fig. 4) and during the simulation it moved in horizontal direction under load caused by an appropriate acceleration pulse.

The simulations were performed in the PAMCRASH as an explicit task, in solver version: Virtual Performance Solution, 2012.0. In all analyzed cases, the integration time step was equal $\Delta t=10^{-3} \mathrm{~ms}$ and the considered simulation time was $300 \mathrm{~ms}$.

For simulations performed in accordance with FAR 25.562 conditions, $14 \mathrm{~g}$ acceleration pulse (Fig. 6) was represented with the curve shown in [8]. In the case of the $19 \mathrm{~g}$ pulse, the acceleration curve was considered by scaling the $14 \mathrm{~g}$ pulse to the conditions defined in FAR 23.562.

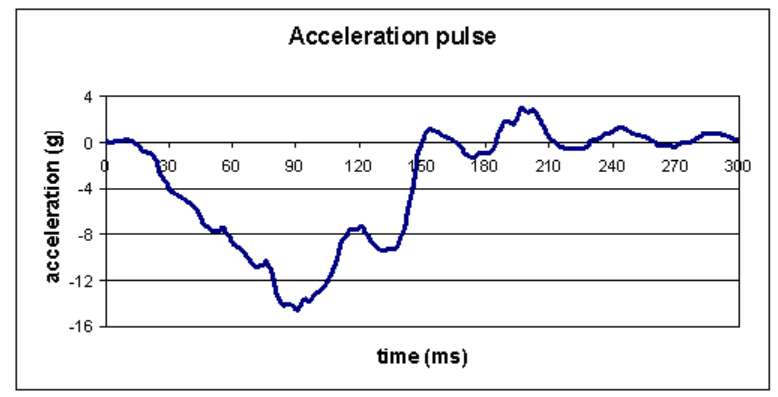

Fig. 6. 14g acceleration peak used in simulated FAR 25.562 tests 


\subsection{Virtual human body model - VIRTHUMAN}

In numerical simulations, a virtual human body model, the VIRTHUMAN, was used. It is a hybrid model that combines rigid bodies and deformable segments. Its basic skeleton is represented with a multi-body system (MBS) forming an open tree structure. In this structure, rigid bodies are connected via joints, that is, non-linear springs and dampers (Fig. 7). In some body parts, additional joints are considered to account for possible fractures. Lower extremity, for instance, is formed of three parts, namely the upper leg, the lower leg and the foot, connected with the knee joint and the ankle joint. The upper and the lower leg, however, are formed of four rigid bodies connected via "breakable" joints (Fig. 8).

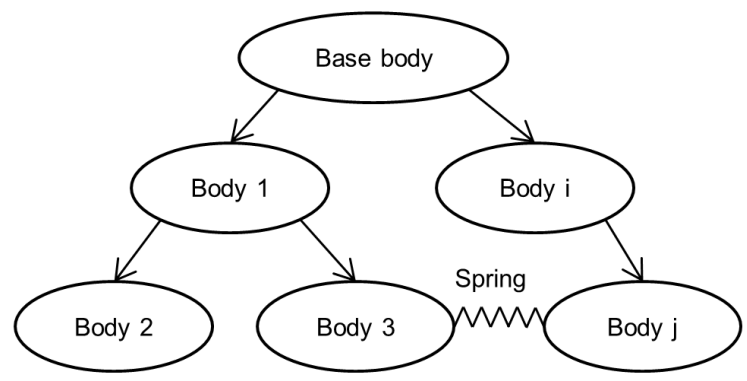

Fig. 7. Basic skeleton of the VIRTHUMAN is formed as a multi-body system

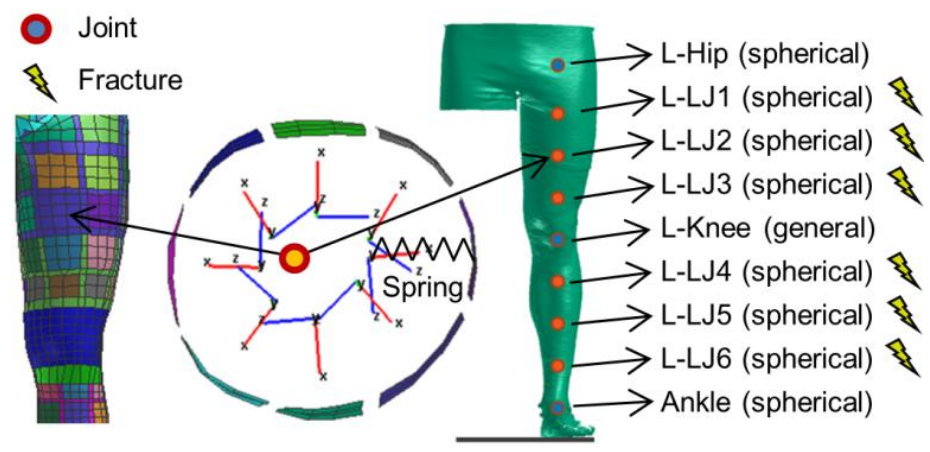

Fig. 8. Breakable joints and the segmentation of the model

The surface of the body is formed of rigid segments. Each segment, however, is connected via a translational joint (non-linear spring and a damper) to the basic skeleton (Fig. 7). Material characteristics of translational joints represent viscoelastic properties of soft tissues. Hence, deformability of soft tissues is taken into account in the model. Division of each body part into multiple segments, each of them with its own translational joint, makes it possible to account for loading and deformations in multiple directions. 
The referential model is created as a 50th percentile male using the the CEESAR (Centre Européen d'Etudes de Sécurité et d'Analyse des Risques) database. However, an extensive anthropometric database [20] was used to complete an automatic scaling tool. Hence, the diversity of population is taken into account in the model. Human body representatives for both genders of various heights, weights and age can be considered (Fig. 9). For details on scaling of the VIRTHUMAN model see [12].

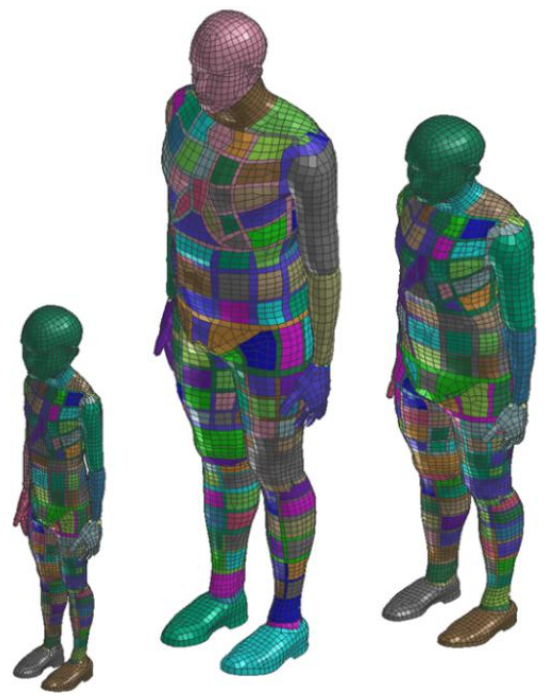

Fig. 9. Scaled VIRTHUMAN. 6-years-old male, $110 \mathrm{~cm}, 17 \mathrm{~kg}$ (left); 40-years-old male, $190 \mathrm{~cm}$, $104 \mathrm{~kg}$ (middle); 70-years-old-male, $150 \mathrm{~cm}, 90 \mathrm{~kg}$ (right)

To ensure biofidelity of the model, extensive validation tests were performed. Individual body parts, namely the head, neck, shoulder, thorax, abdomen, pelvis, knee, femur and tibia were validated using the comparison with available experimental data. Also, full-scale tests, namely the sled test and the pedestrian test were performed. Various impacters, directions and impact velocity levels were used to ensure the model to be multi-purpose, that is useful in complex crash scenarios. See [13] for details.

From the application point of view, the VIRTHUMAN profits from its MBS nature in terms of low computational time and also possibility to perform simulations with multiple occupants or pedestrians. Scaling algorithm implemented make it possible to consider various representatives. Thanks to the application of deformable segments, elasticity of soft tissues is considered. Therefore, together with accelerations and velocities, forces and deformations of individual body parts can be calculated. Calculation of standard injury criteria is included in the model. Thanks to breakable joints, fractures of femur and tibia are taken into account. 


\section{Analyses results}

\subsection{Experimental tests data}

From all experimental tests performed at the NIAR [8] to investigate the ATD body responses as well as hardware reactions, nine of them, representing the $60^{\circ}$ test, were chosen and described in [14]. In all presented cases, the seat was equipped with a two-point belt system (only lap belt). The tests included three configurations and each configuration was repeated three times to obtain data necessary to assess repeatability. Table 5 summarizes basic data concerning the performed experimental tests [14].

Table 5.

$60^{\circ}$ tests performed at NIAR [8] described in [14]

\begin{tabular}{|c|c|c|c|c|c|}
\hline \multicolumn{6}{|c|}{ Experimental Tests } \\
\hline \multicolumn{2}{|c|}{ Part 23.562 conditions } & \multicolumn{2}{|c|}{ Part 25.562 conditions } & \multicolumn{2}{|c|}{ Part 25.562 conditions } \\
\hline \multicolumn{2}{|c|}{$\begin{array}{l}\text { Acceleration peak }-19 \mathrm{~g} \\
\text { Seat type - rigid }\end{array}$} & \multicolumn{2}{|c|}{$\begin{array}{c}\text { Acceleration peak }-14 \mathrm{~g} \\
\text { Seat type - rigid }\end{array}$} & \multicolumn{2}{|c|}{$\begin{array}{l}\text { Acceleration peak - } 14 \mathrm{~g} \\
\text { Seat type - cushioned }\end{array}$} \\
\hline 1 & Test no. $07324-13$ & 1 & Test no. 06165-7 & 1 & Test no. 06165-21 \\
\hline 2 & Test no. $07324-14$ & 2 & Test no. 06165-8 & 2 & Test no. 06165-22 \\
\hline 3 & Test no. $07324-15$ & 3 & Test no. 06165-28 & 3 & Test no. 06165-23 \\
\hline
\end{tabular}

The conditions and the results of these tests were used as a reference for numerical simulations conducted by the authors. In all cases, the peak of loads obtained from the calculations could be compared directly with the values presented in [14], while experimental curves were read from the printout and then compared with simulation curves, which could influence the precision of time histories analyses.

\subsection{Simulation results - comparison with experimental data}

\subsubsection{Part 25.562 14 G’s Rigid seat test}

In the course of a simulation, two main phases can be distinguished. At the first stage, after application of acceleration pulse, the body is pushed into a seat pan, associated with visible deflection of the upper legs and with slight let-up of the lap belt. In parallel, upper legs start to slide on the seat pan surface and the head starts to rotate forward. This motion continues to the moment $(t \approx 100 \mathrm{~ms})$ when the pelvis and upper legs are max. compressed and the belt becomes fully tensioned again. At the end of this phase of motion, the force affecting the lumbar spine reaches the maximum value of 4208 N (946 lbf). During the second phase of motion, the body rotates around the lap belt until upper torso and the head reach the position of their maximum deviation $(t \approx 200 \mathrm{~ms}$ ) (Fig. 10).

In the case of the Virthuman model, rotation of the body is not as high as in the case of the FAA HIII dummy. This difference is seen when comparing selected 


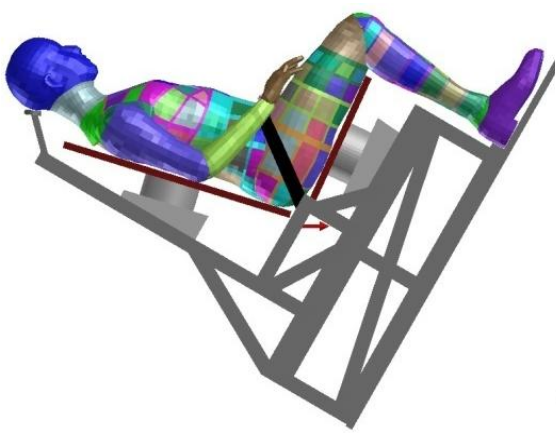

(a)

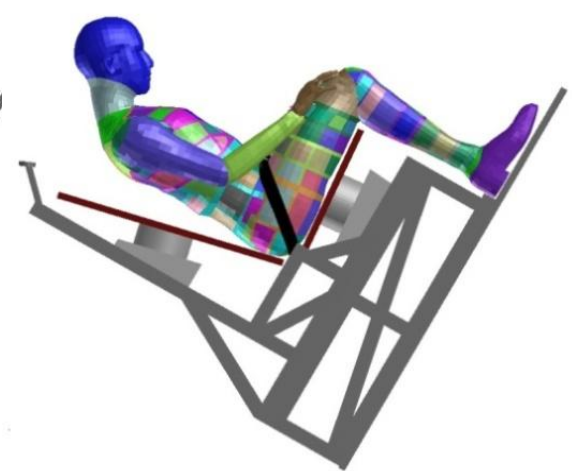

(b)

Fig. 10. Selected frames from computer simulation: $t=0 \mathrm{~ms}$ (left) and $t=200 \mathrm{~ms}$ (right)

frames taken from simulation (Fig. 10) with those from experiment (shown in [14]). Moreover, in both phases of motion, the simulation showed that the lap belt tension significantly influences the visible deflection of the Virthuman abdomen (see Fig. 15).

Despite observed differences in kinematic behaviour, time history of the compression force registered during simulation (Fig. 11) is basically very similar to curve recorded during experimental test shown in [14]. The difference between maximum value of load calculated during simulation and the average value obtained from experiments is $187 \mathrm{~N}$ (42 lbf). So, relative difference is approximately $4.2 \%$. The simulation curve is slightly delayed and widened in comparing with the experimental curve, which is caused by the difference in mechanical response between the FAA HIII dummy and the Virthuman model of the human body. As the probably predominant reason for this fact one can consider differences in deformability of particular body segments. The results of the test are summarized in Table 6.

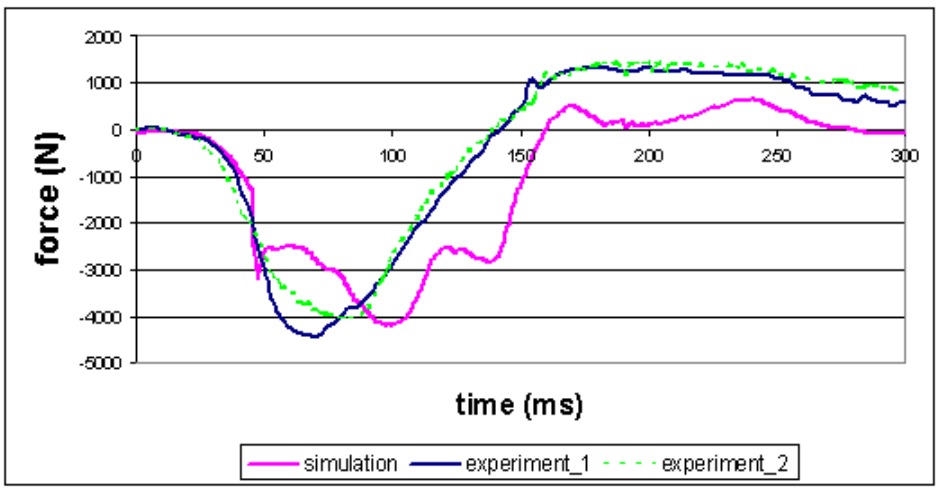

Fig. 11. Compression force affecting the lumbar spine - comparison 
Table 6.

Simulation's result in comparison with experiments

\begin{tabular}{|l|c|c|c|c|}
\cline { 2 - 4 } \multicolumn{1}{c|}{} & Load & Seat type & $\begin{array}{c}\text { Lumbar peak load } \\
\text { N (Ibf) }\end{array}$ & $\begin{array}{c}\text { Average peak } \\
\text { N (Ibf) }\end{array}$ \\
\hline \multirow{3}{*}{ Experimental tests } & $14 \mathrm{~g}$ & Rigid & $4506(1013)$ & \multirow{2}{*}{$4394(988)$} \\
\cline { 2 - 4 } & $14 \mathrm{~g}$ & Rigid & $4573(1028)$ & \\
\cline { 2 - 4 } & $14 \mathrm{~g}$ & Rigid & $4110(924)$ & \multirow{2}{*}{$4208(946)$} \\
\hline Simulation & $14 \mathrm{~g}$ & Rigid & $4208(946)$ & \multicolumn{3}{|c}{} \\
\hline
\end{tabular}

\subsubsection{Part 23.56219 G's Rigid seat test}

In the case of test with acceleration peak of $19 \mathrm{~g}$, the course of a simulation with two main phases is similar like that in the case of test with peak of $14 \mathrm{~g}$. The main difference is that some effects observed in the first stage of simulation are increased. The body is pushed into the seat pan more sharply. It results in significant increasing the compression force, which reaches the maximum value of $5325 \mathrm{~N}$ (1197 lbf). In consequence, the first phase of motion is shortened and the second phase starts at the time of $65 \mathrm{~ms}$.

Maximum rotation of the Virthuman body is significantly lower than in case of the FAA HIII dummy model. So, the difference in kinematics of the body is increased. Like in the previous case, the lap belt tension significantly influences visible deflection of the Virthuman abdomen.

Time history curves (Fig. 12.) and results (Table 7) are shown below. Although the shape of time histories of load obtained from the simulation and from the experiment are similar, increasing acceleration pulse causes that significant difference in curve magnitude. The peak of compression force calculated during the simulation is much lower than the average peak force measured in experimental tests and the difference reaches the value of $2452 \mathrm{~N}$ (551 lbf). So, the relative difference is

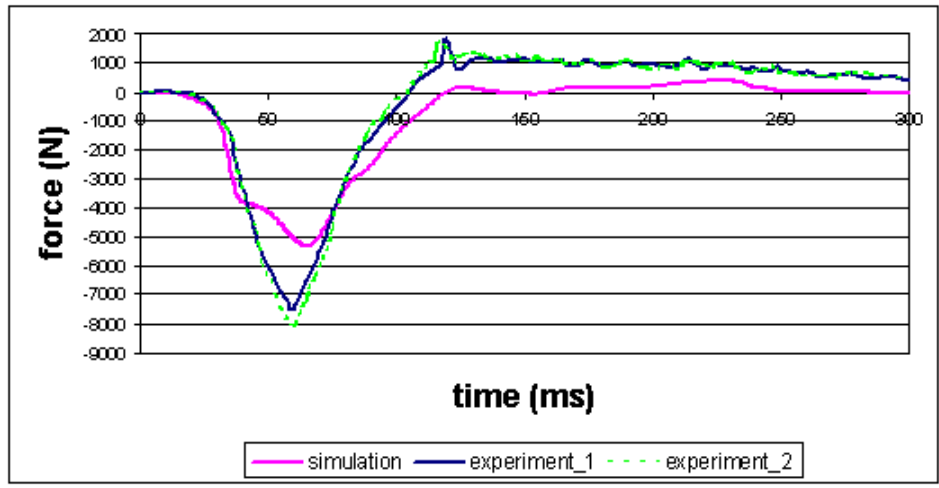

Fig. 12. Compression force affecting the lumbar spine - comparison 
approximately equal to $31.5 \%$. One can notice that the force obtained from simulation is below the tolerance level ( $6672 \mathrm{~N}$ - see Table 3), while that recorded in experiments clearly exceeds this level.

Table 7.

Simulation's result in comparison with experiments

\begin{tabular}{|l|c|c|c|c|}
\cline { 2 - 4 } \multicolumn{1}{c|}{} & Load & Seat type & $\begin{array}{c}\text { Lumbar peak load } \\
\text { N (Ibf) }\end{array}$ & $\begin{array}{c}\text { Average peak } \\
\text { N (Ibf) }\end{array}$ \\
\hline \multirow{3}{*}{ Experimental tests } & $19 \mathrm{~g}$ & Rigid & $7615(1712)$ & \multirow{3}{*}{$7775(1748)$} \\
\cline { 2 - 4 } & $19 \mathrm{~g}$ & Rigid & $7722(1736)$ & \\
\cline { 2 - 4 } & $19 \mathrm{~g}$ & Rigid & $7998(1798)$ & \multicolumn{1}{|c|}{$5325(1197)$} \\
\hline Simulation & $19 \mathrm{~g}$ & Rigid & $5325(1197)$ & 5325 \\
\hline
\end{tabular}

\subsubsection{Part 25.562 14 G's Cushioned seat test}

In the case of the test with seat pan equipped with a cushion, one can observe clear difference in rotation of the body between the Virthuman model (Fig. 13) and the FAA HIII (shown in [14]). It could result from the fact that, during the Virthuman sitting procedure, deformation of the cushion is lower than deformation of the real cushion on experimental stand. It, in turn, influences the cushion behaviour in the first stage of motion and modifies human body response.

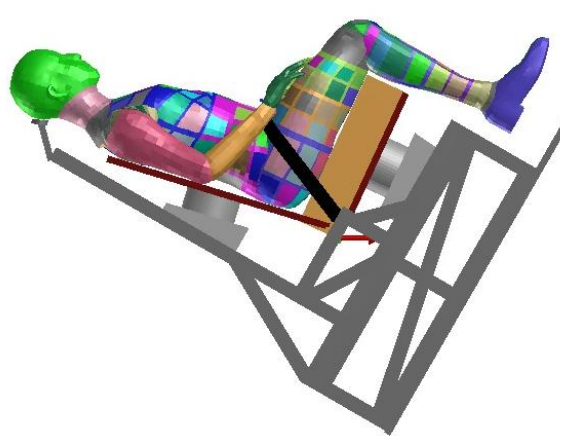

(a)

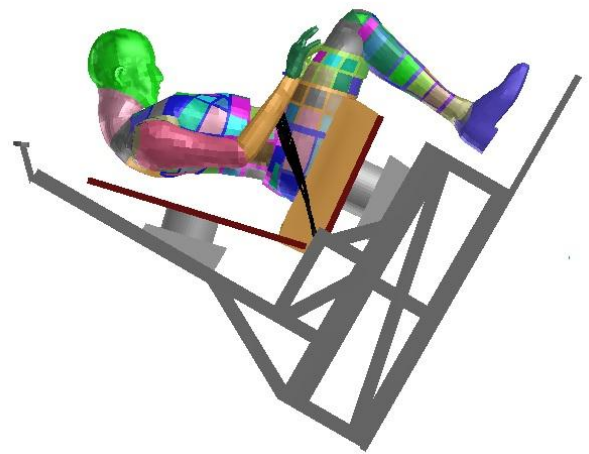

(b)

Fig. 13. Selected frames from: $t=0 \mathrm{~ms}$ (left) and $t=160 \mathrm{~ms}$ (right)

In the simulation model, application of a cushion leads to elongation of the "pushing phase". It also makes it possible to increase the range of sliding on the seat pan surface and amplify the effect of let-up of the belt, which in turn modifies the "rotation phase". The peak of load affecting the lumbar spine reaches the maximum value of $10511 \mathrm{~N}(2363 \mathrm{lbf})$ at the time $t=110 \mathrm{~ms}$ (Fig. 14) and is higher than the experimental one. 
The comparison of time histories of compression force shows only minor differences (slight time delay in the case of simulation curve). The difference between the maximum value of load calculated during simulation and the average value obtained from experiments is equal to $810 \mathrm{~N}(182 \mathrm{lbf})$. So, the relative difference is approximately equal to $8.3 \%$. The tests results are given in Table 8 .

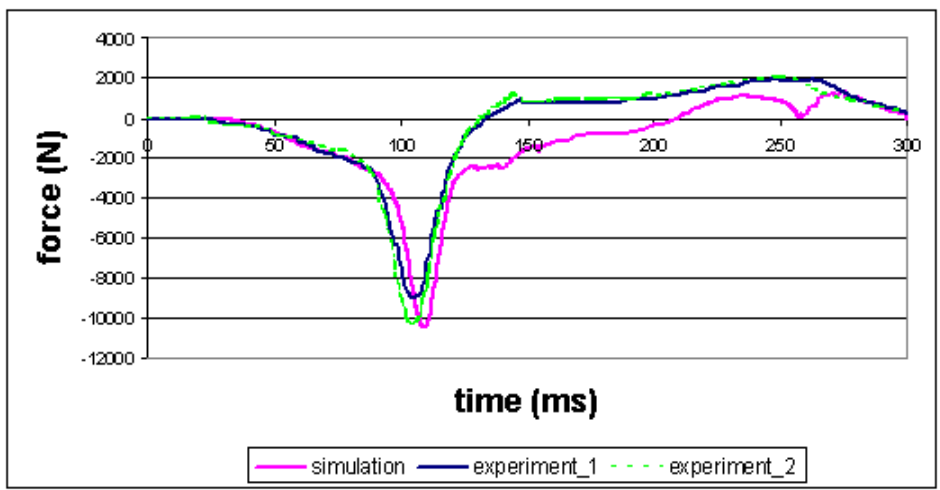

Fig. 14. Compression force affecting the lumbar spine - comparison

Table 8.

Simulation's result in comparison with experiments

\begin{tabular}{|l|c|c|c|c|}
\cline { 2 - 4 } \multicolumn{1}{c|}{} & Load & Seat type & $\begin{array}{c}\text { Lumbar peak load } \\
\text { N (Ibf) }\end{array}$ & $\begin{array}{c}\text { Average peak } \\
\text { N (Ibf) }\end{array}$ \\
\hline \multirow{3}{*}{ Experimental tests } & $14 \mathrm{~g}$ & Cushioned & $9083(2042)$ & \multirow{3}{*}{$9702(2181)$} \\
\cline { 2 - 4 } & $14 \mathrm{~g}$ & Cushioned & $9657(2171)$ & \\
\cline { 2 - 4 } & $14 \mathrm{~g}$ & Cushioned & $10373(2332)$ & \multirow{2}{*}{$10511(2363)$} \\
\hline Simulation & $14 \mathrm{~g}$ & Cushioned & $10511(2363)$ & \multicolumn{2}{|c|}{} \\
\hline
\end{tabular}

In both cases, one can notice that the peak force significantly exceeds the tolerance level (Table 3). The analysis of the simulation results allows us to observe that the application of a cushion leads to an increase in the level of force affecting the lumbar spine. It seems to be, at the first glance, a questionable phenomenon, but, at the same time, it is perfectly consistent with the results experiments reported in [14].

\subsection{Virthuman model versus dummy response}

Although lumbar loads signals from the experimental tests and the Virthuman model's response, compared numerically, show high level of consistence, some minor differences in the whole body kinematics, associated with some peculiar deformation models of the Virthuman model, should be reported. At this stage, it is assumed that the differences may be caused by the fact that we compare the response of the hardware dummy that, due to its design limitations [3], is more stiff than the 


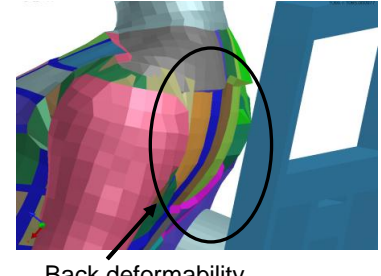

Back deformability

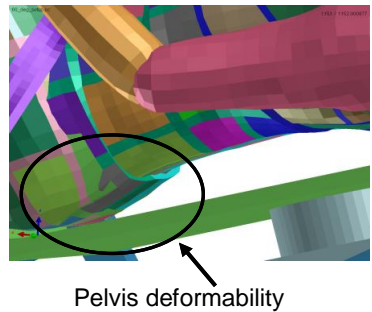

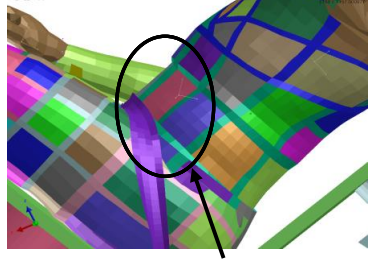

Abdomen deflexion

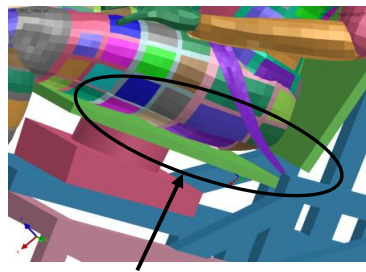

Upper leg deflexion

Fig. 15. Different modes of deformation observed in the course of simulations in the case of Virthuman model

real human body represented by the Virthuman. Fig. 15 shows peculiar modes of the Virthuman deformation that influence neither load levels in the conducted runs nor the stability of the model, but may cause some contact problems when applied further in other configurations.

\section{Conclusions}

During the research, numerical test setups described in FAR 23.562 and 25.562 regulations were prepared. One conducted the study with the Virthuman numerical body model focused on vertical loads affecting the lumbar spine during the crash. The performed analyses show numerical stability of the human model and a satisfactory agreement between experimental loads based on the FAA HIII dummy [14] and the simulated Virthuman responses. In that sense, the Virthuman model, although originally developed for automotive analyses, shows also great potential to become a valuable tool for applications in aviation crashworthiness and/or safety analyses, as well.

The increase of force affecting the lumbar spine in the case of application of a cushion is a bit surprising, but in-line with experimental results. Despite the expectations, there is an experimental evidence proving the increase of force affecting the lumbar spine when the cushion is used. The VIRTHUMAN model confirms these observations. In simulations, application of a cushion also leads to an increase of the force in lumbar spine area. Therefore, the VIRTHUMAN might be a suitable tool for possible investigation of this effect.

A few peculiar deformation modes of the Virthuman outer body model were observed in abdomen, back, pelvis and upper legs which cause that the responses of 
the Virthuman differ from those of experimental dummy. However, these deformation don't change the overall loading pattern of the model's response, but certainly need some further attention.

It is recommended and planned to continue the presented research by:

- Conducting series of simulation runs in the same setups with the FAA HIII model to have a virtual comparison linkage between the dummy response from experiments and the human virtual model simulation results to more precisely look into and eliminate or omit the effect of dummy biofidelic limitations in the analyses.

- Preparing and conducting safe experimental volunteer tests targeted at examining lumbar spine loading and confronting the results with the models' responses.

- Utilizing the existing experimental data based on PW-5 glider sled crash [21, 22], owned by the Warsaw University of Technology, to investigate other than the FAR modes of human responses in crash environment [23, 24].

- Evaluating the FAR seat certification procedures for new conceptual aircraft seat design (FEM).

\section{Acknowledgements}

This work has been supported by the European Union in the framework of European Social Fund through the „Didactic Development Program of the Faculty of Power and Aeronautical Engineering of the Warsaw University of Technology" and by Internal project SGS-2016-059 „Computer modeling and monitoring of human body used for medicine" of the University of West Bohemia.

Manuscript received by Editorial Board, July 06, 2016;

final version, September 20, 2016.

\section{References}

[1] Improved Seats in Air Carrier Transport Category Airplanes. 14 CFR Part 121. [Docket No. FAA-2002-13464 2, Amendment No.121-315] Final Rule. Federal Register: September 27, 2005. http://rgl.faa.gov/Regulatory_and_Guidance_Library/rgfinalrule.nfs/0/ df02e83a968757e68625708a00714f48.

[2] https://www.easa.europa.eu/document-library/bilateral-agreements.

[3] T.R. Hurley and J.M. Vandenburg. Small Airplane Crashworthiness Design Guide. Simula Technologies TR-98099, Phoenix, April 2002.

[4] Dynamic Evaluation of Seat Restraint Systems and Occupant Protection on Transport Category Airplanes / with Change 1. AC 25.562-1B. Federal Aviation Administration. January 10, 2006.

[5] S.J. Hooper and M.J. Henderson. Development and Validation of an Aircraft Seat Cushion Component Test - Volume I. Report No. DOT/FAA/AR-05/5,I, March 2005.

[6] P. Bhonge. A methodology for aircraft seat certification by dynamic finite element analysis. Ph.D. Thesis, Wichita State University, 2008. 
[7] Methodology for Dynamic Seat Certification by Analysis for use in Parts 23, 25, 27 and 29 Airplanes and Rotorcraft. AC 20-146. Federal Aviation Administration, May 19, 2003.

[8] G. Olivares. Dynamic Seat Certification by Analysis: Volume II - FAA Hybrid III ATD Dynamic Evaluation NIAR Test Series. NIAR Technical Report FAA-002D, Wichita, KS, September 2009.

[9] MADYMO Human Body Models Manual. Release 7.5. TASS BV, Delft, The Netherlands, 2013.

[10] MADYMO Model Manual. Release 7.5. TASS BV, Delft, The Netherlands, 2013.

[11] J. Maňas, L. Kovàř, J. Petřík, H. Čechová and S. Špirk S. Validation of human body model VIRTHUMAN and its implementation in crash scenarios. In Advances in Mechanisms Design: Proceedings of TMM 2012, pages 351-356, doi:10.1007/978-94-007-5125-5_46.

[12] L. Hyncik, H. Čechová H., L. Kovár and P. Blaha. On Scaling Virtual Human Models. SAE Technical Paper 2013-01-0074, March 2013, doi: 10.4271/2013-01-0074.

[13] J. Vychytil, J. Manas, H. Cechova, S. Spirk L. Hyncik and L. Kovar. Scalable multi-purpose virtual human model for future safety assessment. SAE Technical Paper 2014-01-0534, January 2014, doi: 10.4271/2014-01-0534.

[14] O. Oliva-Perez. Evaluation of the FAA Hybrid III 50th percentile anthropometric test dummy under the FAR 23.562 and 25.562 emergency landing conditions for the combined horizontalvertical dynamic loading. Master Thesis, Wichita State University, 2010.

[15] U.S. Department of Transportation. 49 Code of Federal Regulations Part 572, Subpart B.

[16] Emergency landing dynamic conditions. 14 CFR 23.562. Federal Aviation Administration. FAA webpage.

[17] Emergency landing dynamic conditions. 14 CFR 25.562. Federal Aviation Administration. FAA webpage.

[18] www.niar.wichita.edu/researchlabs/pdf/CDL_Facilities_Equipment_March2012.pdf.

[19] PAMCRASH Handbooks.

[20] P. Blaha. Anthropometric studies of the Czechoslovak population from 6 to 55 years. volume 1, part 2, Praha, 1987 (in Czech).

[21] L. Lindstedt. Dynamical behaviour of a composite cockpit of PW-5 glider when hitting against a ground barrier - the issue of pilot's safety. Ph.D. Thesis, Warsaw University of Technology, 2010. (in Polish).

[22] L. Lindstedt, M. Rodzewicz, C. Rzymkowski and K. Kędzior. Experimental study of impact phenomena in case of a composite glider. Technical Soaring, 33(2):54-62, 2009.

[23] L. Lindstedt, C. Rzymkowski and K Kędzior. Experimental and numerical investigations on pilot-glider-environment system during the impact against a deformable barrier. In Proceedings of the 13th World Congress in Mechanism and Machine Science, pages 1-8, Guanajuato, México, 19-25 June, 2011.

[24] L. Lindstedt. Numerical simulation of glider crash against a non-deformable barrier. Archive of Mechanical Engineering, 58(2):245-265, 2011. doi: 10.2478/v10180-011-0017-3.

\section{Symulacje numeryczne reakcji modelu ciała człowieka na obciążenia dynamiczne zdefiniowane w normach FAR 23.562 i 25.562 - badania wstępne}

Streszczenie

Głównym celem pracy była analiza odpowiedzi modelu numerycznego ciała człowieka na obciążenia typowe dla wypadków lotniczych i porównanie rezultatów z wynikami testów eksperymentalnych opisanych $\mathrm{w}$ literaturze. Badaniu poddano nowo opracowany model człowieka, przeznaczony do symulowania dynamiki ciała ludzkiego poddanego różnym rodzajom i kierunkom obciążeń, o nazwie VIRTHUMAN. Model jako całość, podobnie jak jego pojedyncze komponenty, 
został wcześniej zweryfikowany w oparciu o wyniki testów eksperymentalnych, które dowiodły jego przydatności do symulowania dynamiki ciała człowieka poddanego obciążeniom typowym dla tych występujących podczas wypadków samochodowych. Jak do tej pory nie przeprowadzono jednak badań uwzględniających siły o dominującej składowej pionowej (działające wzdłuż kolumny kręgosłupa), typowe dla wypadków lotniczych. Z powodu małej liczby dostępnych danych eksperymentalnych, badania ograniczono do przypadków opisanych w paragrafie (b)(1) części 23.562 oraz 25.562 regulacji FAR. Przeprowadzone analizy polegały na porównaniu siły ściskającej zarejestrowanej w odcinku lędźwiowym kręgosłupa manekina FAA HIII (model eksperymentalny) i VIRTHUMAN-a (model numeryczny). Uzyskane rezultaty dowiodły stabilności numerycznej modelu i zadowalającej zgodności jego dynamiki z wynikami testów eksperymentalnych. Pozwala to stwierdzić, że model VIRTHUMAN, przeznaczony pierwotnie do analiz w przemyśle samochodowym, może się stać bardzo przydatnym narzędziem do badań nad bezpieczeństwem podczas wypadków lotniczych. 